\title{
Monitoring environmental pollution using a stalagmite from Hungary
}

\author{
Zoltan Siklósy' ${ }^{1}$, A. Demény ${ }^{1}$, S. Pilet² ${ }^{2}$, Sz. Leel-Ossy33, K. Lin and C.C. Shen ${ }^{4}$ \\ 'Institute for Geochemical Research, Hungarian Academy of Sciences, Budapest; siklosy@geochem.hu \\ 2Institute of Mineralogy and Geochemistry, University of Lausanne, Switzerland \\ ${ }^{3}$ Eotvos University, Budapest, Hungary \\ ${ }^{4}$ Department of Geosciences, National Taiwan University, Taipei
}

Speleothems are well known paleoclimate archives but their potential for monitoring environmental pollution has not been fully explored (e.g., Frisia et al., 2005; Fairchild et al., 2006; Borsato et al., 2007; Perrette et al., 2008). This study deals with an actively growing stalagmite whose trace-element concentration suggests anthropogenic contamination, rather then natural forcing. Our objective was to determine the possible effect of the four-decade-long uranium $(U)$ ore mining activity on the environment, as recorded by a cave deposit.

The Trio Cave $\left(46.7^{\circ} \mathrm{N}, 18.9^{\circ} \mathrm{E}\right)$ is located in the western part of the Mecsek Mountains (S. Hungary) at the base of the Szuado Valley, approx. $1.5 \mathrm{~km}$ east of the nearest entrance and air shaft of the Mecsek uranium mine (mine-pit no. IV). The karst system developed in the Triassic Lapis Limestone and the cave is ca. $200 \mathrm{~m}$ long. There is one artificially enlarged entrance (opened once in 1969 and finally in 1997), which intermittently acts as a sinkhole for the Orfú creek, with a catchment area of $3.5 \mathrm{~km}^{2}$. A stalagmite located about $150 \mathrm{~m}$ into the cave was drilled and the 42 $\mathrm{cm}$-long core was investigated for stable isotope and trace element composition using continuous-flow mass spectrometry and laser-ablation inductively coupled plasma mass spectrometry (ICP-MS), respectively (Siklósy et al., 2007).

The uppermost ca. $3 \mathrm{~cm}$ of the core were selected for this study (Fig. 1a), which represents the last few hundred years (based on an estimated growth rate of $0.05 \mathrm{~mm} /$ year by ${ }^{230} \mathrm{Th}$ age dating of older parts of the core).

\section{Geochemical results}

The older part of the $3-\mathrm{cm}$ section is characterized by systematic co-variations between $U$ and Phosphorus $(P)$ concentrations, and $P$ concentrations and $\delta^{13} \mathrm{C}$ values, which can be related to soil activity (Figs. 1b, 1c). Silica (Si), aluminium (Al), thorium (Th) are positively correlated, and their concentrations increased strongly in the uppermost ca. $3 \mathrm{~mm}$, due to the elevated detrital content of the stalagmite (Fig. 1d). With increased detrital input, the $\mathrm{U}$ concentration also increased radically (especially in the topmost $1.3 \mathrm{~mm}$ ), start- ing from a background value of 0.2-0.3 ppm, increasing gradually to about $2 \mathrm{ppm}$, followed by constant values for about 0.5 $\mathrm{mm}$, and then declining to about $1.5 \mathrm{ppm}$ (Figs. 2a, and 2d).

The increase in $U$ concentration coincided with a significant decrease in $\delta^{234} U_{\text {initial }}$ values suggesting contribution from a $U$ source different from the natural weathering input (Fig. 2a). This is also supported by a change in the $P / U$ ratio and much weaker correlation of the $U$ concentrations with $\mathrm{P}$ (Fig. 2b) in the U-enriched section of the stalagmite ("mining-period"). According to the average growth rate of the stalagmite, this period represents the last $30-50$ years.

\section{Origin of pollution}

Possible $U$ sources are fertilizers used in agriculture, industrial pollution (e.g., ash

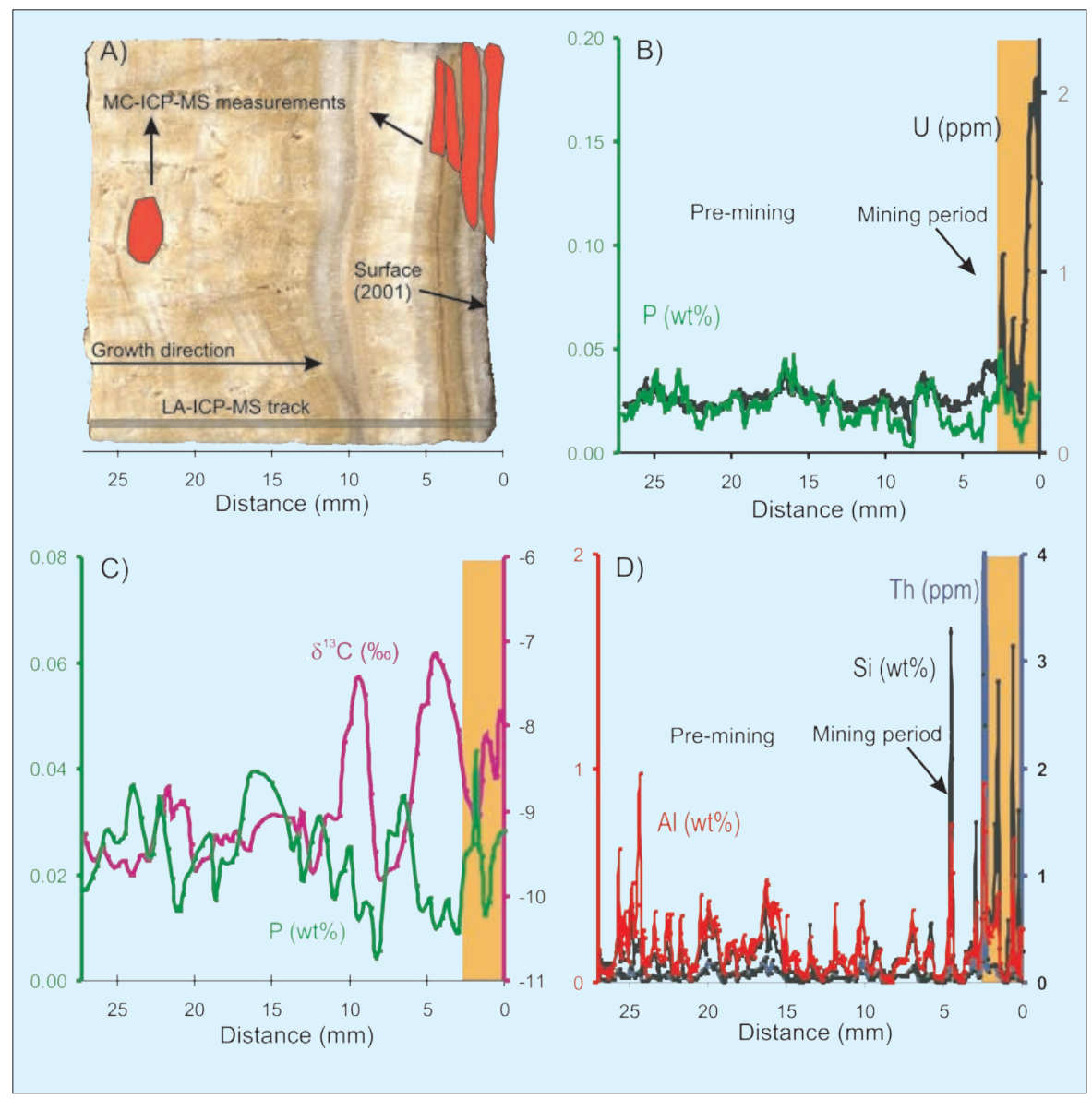

Figure 1: a) Image of the sub-recent part of Trio stalagmite core (southern Hungary). Gray bar shows the position of the trace-element profile. Position of the MC-ICP-MS data reported in Fig. $2 b$ is indicated by the red regions. $\boldsymbol{b}$ ) Phosophorus (P) vs. Uranium (U) contents; $\boldsymbol{c})$ Stable C isotope and P concentrations of the stalagmite; $\boldsymbol{d}$ ) Th, Al and $\mathrm{SiO}_{2}$ content. All data are plotted against the distance from the active surface of the stalagmite (time of collection: 2001). Orange shaded area represents approx. period of mining activity. from coal-heated power plants), and U ore mining in the vicinity of the cave site. Fertilizers may contain considerable amounts of $U$ (10-360 ppm, Hamato et al., 1995), however, the lack of agriculture in the valley and the region around the cave, consistent with the absence of high $\mathrm{P}$ concentrations (Fig. 1b) in the topmost section of the speleothem, strongly argues that fertilizers are not the source of the high $U$ values. Coal-derived pollutants can likewise be exluded as a source for the high $\mathrm{U}$ concentrations in the stalagmite, as the only major industrial city and power plant in the southern part of Hungary (Pécs) is approx. $12 \mathrm{~km}$ from the cave. In addition, the dominating wind currents flow in the opposite direction and coal ash is rich in metals (Co, V, Zn, etc.) that were not enriched in the stalagmite. 

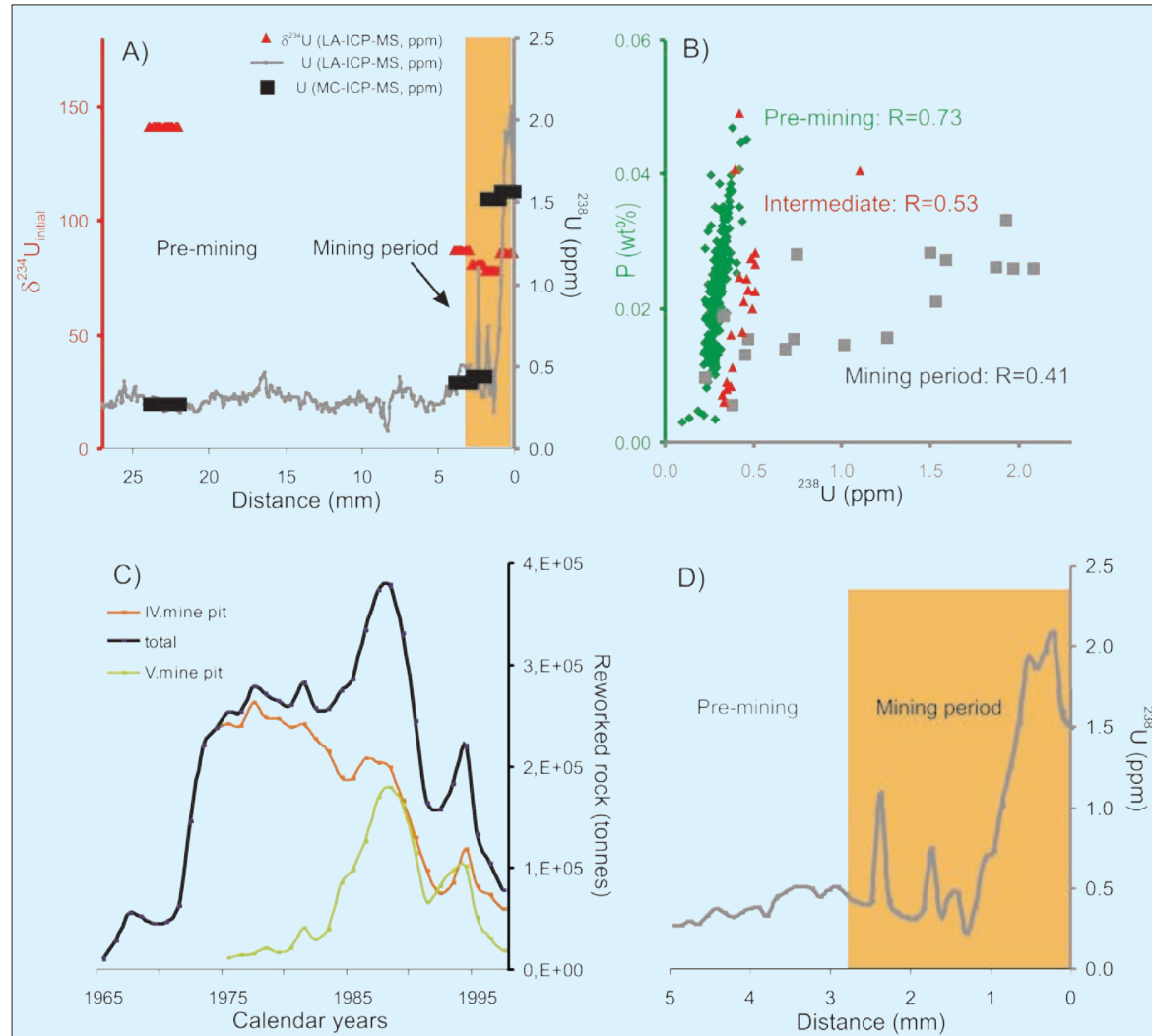

Figure 2: a) Uranium ( ${ }^{238} \mathrm{U}$ ) concentration (measured independently by Laser Ablation-and MC-ICP-MS) and $\delta^{234} \mathrm{U}$ values of the Trio stalagmite. Data are plotted against the distance from the active surface of the stalagmite (time of collection: 2001). b) Correlation between $P$ and $U$ for assumed pre-mining and mining period of the studied sample. Intermediate period is also indicated. Note the reduction of the $R$-values and the change in the $P / U$ ratio. c) History of $U$ ore production, as shown by the mass of reworked U-bearing sandstone. $d)^{238} U$ concentration for the topmost $5 \mathrm{~mm}$ of the stalagmite representing approx. the last 100 years of growth. Orange shaded area represents approx. period of mining activity.

The third possible source of $U$ is the 40-year-old Mecsek uranium mine, which produces ca. 500 tons of $U$ concentrate per year and has reworked millions of tons of solid material (Bánik et al., 2002). U production in S. Hungary started in 1957 and was expanded closer to the cave site in 1969 (Fig. 2c), covering a mining plot area of ca. $65 \mathrm{~km}^{2}$. The deep-level ore production ended in 1997 and remediation of the mine site has since been completed.

The possible relationship between high $U$ concentration in the most recent stalagmite section and $U$ ore mining was investigated by the comparison of the measured $U$ concentration (Fig. 2d) and the mining intensity (Fig. 2c). The deep level of the mine was ventilated by air shafts, therefore the total mass of the exploited U-bearing sandstone and the dust released by the mine's shafts are directly correlated. The water catchment area of the Trio Cave is situated at a higher elevation than the closest mine pit (no. IV), which excludes the possibility that $U$ was fluvially transported from the mining area to the cave. Eolian transport of dust released from air shafts and subsequent dust deposition, however, have been identified by previous studies of soil, plants and leaves
(Mecsekérc Ltd., unpublished reports). Although the higher proportion of washedin particles can be clearly followed by the elevated detrital content of the stalagmite (Fig. 1a), Fig. 1d clearly illustrates that the exceptionally high $\mathrm{Si}, \mathrm{Al}$ and Th peaks coincide with both dark and U-enriched layers (Fig. 1b). The gradual increase in $U$ concentration to the highest values ( 0.2 to $2.1 \mathrm{ppm}$ ) may be due to the weathering of the mine-derived dust that settled in the catchment area. Plotting of $P$ vs. $U$ can be used to separate the pre-mining and the mining section (at ca. $1.7 \mathrm{~mm}$ from the top of the sample), as they are characterized by different elemental ratios (Fig. 2b).

\section{Mobility and transportation of $U$}

Considering the mobilility of the $\mathrm{U}(\mathrm{VI})$ uranyl ion in oxidized environments, the major part of polluting $U$ is not expected to accumulate in the soil zone but would rather be transported into the vadose zone (zone between the ground surface and the water table). Natural aquifer systems always contain organic macromolecules (e.g., wood degradation products, humic acids) originating mostly from the soil-zone solutions. In the case of $\mathrm{U}(\mathrm{VI})$, humic acid exhibits a clear mobilizing ef- fect (Sachs et al., 2005), therefore acting as an aid for the transport of $U$ into the karst system. In solutions of near-neutral $\mathrm{pH}$, the presence of carbonate ions induces the formation of highly soluble uranyl-carbonate complexes, $\mathrm{UO}_{2}\left(\mathrm{CO}_{3}\right)_{3}$ (Finch and Murakami, 1999), minimizing adsorption to soil particles and enhancing $U$ mobility (Elless and Lee, 1998). Finally, $U$ is removed from seepage water by precipitation of carbonates.

To summarize, the relationship between changes in the $U$ content and $\delta^{234} U$ values of the speleothem, and the history of $U$ ore production and pollution strongly suggest a causal link. Our study therefore demonstrates that speleothems can reliably record environmental pollution signals, a hitherto largely unexplored source of information.

\section{Note}

All data are available for download from www.geokemia.hu/ siklosy/index.html

\section{Acknowledgements}

This study was financially supported by the Hungarian Scientific Research Fund (OTKA T 049713) and the Hungarian Scholarship Board (travel grants to Z.S.). Special thanks to the colleagues of Mecsekérc Ltd., the legal successor of the Mecsek Uranium Mining Company, who generously provided ore production data and environmental monitoring reports. Measurements of U-Th isotopic compositions and and ${ }^{230} \mathrm{Th}$ dates were supported by the National Science Council grants (94-2116-M002-012, 97-2752-M002-004-PAE \& -005-PAE to C.C.S.)

\section{References}

Bánik, J., Csicsák, J. and Berta, Zs., 2002: Experience on application of continuous drain trench during the remediation of tailings ponds in Hungary. In: Broder J. M., et al. (Eds), Uranium Mining and Hydrogeology III, 913-921.

Fairchild I.J., Smith C.L., Baker A., Fuller L., Spotl C., Mattey D., McDermott F. and E.I.M.F., 2006: Modification and preservation of environmental signals in speleothems, Earth-Science Reviews, 75(1-4): 105-153.

Frisia, S., Borsato, S., Susini, J. and Somogyi A., 2005: Climate forcings and their influence on Alpine history as reconstructed through the application of synchrotron-based X-ray microfluorescence on layered stalagmites, Archaeometry, 47(2): 209-219.

Hamato, H., Landsberger, S., Harbottle, G. and Panno, S., 1995: Studies of radioactivity and heavy metals in phosphate fertilizer, Journal of Radioanalytical and Nuclear Chemistry, 194(2): 331-336.

Siklosy, Z., Demeny, A., Vennemann, T.W., Kramers, J., Lauritzen, S.E. and Leel-0ssy, Sz., 2007: Middle bronze age climate change recorded in a Hungarian stalagmite: triggering by volcanic activity? Geophysical Research Abstracts, 9: 1607-7962/gra/EGU007-A-00777.

For full references please consult:

www.pages-igbp.org/products/newsletters/ref2008_3.htm 